Güneş, G. ve Demir, M. K. (2020). Okuma yazmayı farklı yazı türleriyle öğrenen öğretmen adaylarının bitişik eğik yazıya ilişkin görüşleri. Ana Dili Eğitimi Dergisi, 8(3), 972-985.

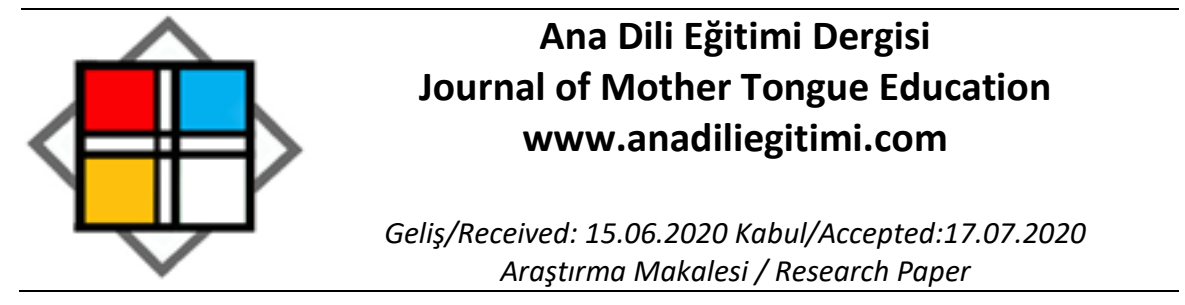

\title{
Okuma Yazmayı Farklı Yazı Türleriyle Öğrenen Öğretmen Adaylarının Bitişik Eğik Yazıya iliş̧kin Görüşleri*
}

\author{
Gözde GÜNEŞ** \\ Mehmet Kaan DEMiR ${ }^{* * *}$
}

\begin{abstract}
Öz
Araştırmanın amacı ilk okuma yazmayı farklı yazı türleriyle öğrenen sınıf öğretmeni adaylarının bitişik eğik yazıya yönelik görüşlerini ve bu görüşlerin cinsiyete ve öğrendikleri yazı türüne göre anlamlı bir farklılık gösterip göstermediğini ortaya çıkarmaktır. Çalışmada nicel araştırma yöntemlerinden betimsel tarama modeli kullanılmıştır. Çalışmanın evrenini 2018-2019 öğretim yılında Çanakkale Onsekiz Mart Üniversitesi Eğitim Fakültesi Temel Eğitim Bölümü Sınıf Eğitimi Anabilim Dalı’nda 3. ve 4. sınıfta öğrenimini sürdüren öğretmen adayları oluşturmuştur. Bu evrenden amaçlı örnekleme yoluyla seçilen 136 sınıf öğretmeni adayı ile çalışma gerçekleştirilmiştir. Veri toplama aracı olarak Çakır (2012) tarafından geliştirilen "Bitişik Eğik Yazıya iliş̧kin Görüş Ölçeği” kullanılmıştır. Elde edilen veriler SPSS 22 programı ile analiz edilmiş, analiz sonuçları frekans ve yüzde olarak gösterilmiştir. Demografik özelliklerle öğretmen adaylarının görüşleri arasındaki farklılaşmaya bakmak adına bağımsız gruplar için t-Testi uygulanmıştır. Ölçek genelinde verilen yanıtlar incelendiğinde; katılımcıların çoğunun bitişik eğik yazıya ilişkin olumsuz görüş belirttikleri sonucuna varılmıştır. Bitişik eğik yazıya yönelik görüşlerde cinsiyete göre anlaml bir farklılık görülmezken; öğrenilen yazı türüne göre bitişik eğik yazıyla öğrenenler lehine anlamlı bir farklılık olduğu görülmüştür.
\end{abstract}

Anahtar Kelimeler: İlk okuma yazma, sınıf eğitimi, bitişik eğik yazı, dik temel yazı

\section{Opinions of Prospective Teachers Who Have Learned to Read and Write with Different Methods Regarding Cursive Handwriting}

\begin{abstract}
The aim of the research is to examine the opinions of prospective classroom teachers who learned to read and write with different methods about the handwriting, and to investigate whether their opinions show a significant difference according to gender and the type of writing method by which they were taught. Descriptive survey model was applied in the research. Teacher candidates in the $3 \mathrm{rd}$ and 4th years of the primary school education department of a state university in the 20182019 academic year form the universe of this research. This study was conducted with 136 teacher candidates who were selected through purposive sampling. In the research, "Opinion Scale on Cursive Handwriting" developed by Çakır (2012) was used. The data obtained were analyzed through SPSS 22 program, the results of the analysis were displayed in frequency and percentage. Independent groups t-Test was administered to differentiate between demographic characteristics and opinions of teacher candidates. As a result of the research; it was found out that most of the participants stated negative opinions about cursive handwriting. While there was no significant
\end{abstract}

\footnotetext{
* Makale Gözde Güneş tarafından yazılan “ilk okuma yazmayı farklı yazı türleriyle öğrenen sınıf öğretmeni adaylarının bitişik eğik yazı ve dik temel yazıyı kullanım durumları" isimli tezden üretilmiştir.

** Sınıf Öğretmeni, Milli Eğitim Bakanlığı, Çanakkale, gozdegunes14@gmail.com, ORCID: https://orcid.org/00000002-3410-8998

*** Prof. Dr., Çanakkale Onsekiz Mart Üniversitesi, Eğitim Fakültesi, Temel Eğitim Bölümü, Sınıf Eğitimi Ana Bilim Dalı, Çanakkale, mkdemir2000@yahoo.com.tr, ORCID: https://orcid.org/0000-0001-8797-0410
} 
difference in the views of cursive handwriting according to gender, according to the type of writing method they were taught with, there was a significant difference in favor of the learners with cursive handwriting.

Keywords: Primary reading and writing, classroom education, cursive handwriting, manuscript handwriting

\section{Giriş}

Akyol (2005)'a göre yazma, insanların iletişim halindeyken kullanmış olduğu en etkili ve kalıcı yollardan biridir. Yazma, düşüncelerimizi ifade ederken gerekli sembol ve işaretleri motorsal olarak üretebilmektir. Köksal (1999: 5)'a göre; yazmanın bilişsel, duyuşsal ve devinişsel olmak üzere üç ayrı boyutu vardır. Elde edilen bilgilerin sıralanarak zihinsel işlemlerden geçirilip yorumlanması yazmanın bilişsel boyutunu, yazıdaki yalınlık, akıcılık, estetik ve okunaklııı duyuşsal boyutunu, defter, kâğıt, kalem kullanımı, yazmadaki kas hareketlerinin eşgüdümü ise devinişsel boyutunu oluşturmaktadır. Yazmanın kolay, hızlı ve okunaklı bir yazı ile gerçekleştirilmesi nitelikli bir eğitim ile mümkündür. Bu yüzden okul hayatına yeni adım atan öğrencilerin etkili ve güzel yazı yazma becerilerini öğrenmeleri üzerinde özellikle durulmaktadır (Babayiğit, Karabay, Metin ve Halıcı, 2018).

Öğrencinin yazma becerisinin gelişmesinde öğretmenin etkisi tartışımaz bir gerçektir. Öğretmenlerin lisans dönemi boyunca aldıkları eğitimler bu meslekte yeterlik kazanmaları açısından büyük önem taşımaktadır. Öğretmen adaylarının yazma becerilerinin ve bu becerilerini hayata geçirebilmelerinin mesleğe adım attıkları zaman öğrencilerinin de yazma becerilerine doğrudan etki edebileceği unutulmamalıdır.

Illk okuma yazma öğretimi öğrencilerin eğitim hayatında kilit bir noktaya sahiptir. Karadağ (2016: 166)'a göre; yazma öğretimi, "kişilerin sosyal, bilişsel ve duygusal gelişimlerine katkı sunmada önemli bir yere sahiptir". Yılmaz (2013: 226)'a göre yazma öğretimi, "öğrencilerin cesaret ve zevk almalarını sağlayıp geçmiş birikimlerden faydalanarak bir adım daha ileri seviyede yazabilir duruma getirmelidir". Bu dönemde verimli geçirilen eğitim yaşantısı hem ilkokulda okuma yazma anlamında hem de ilkokuldan sonra ileriki eğitim kademelerinde başarıda etkin rol oynayacaktır. Bu nedenle öğrencilere ilk okuma yazmanın temel becerilerini kazandırmak büyük önem taşımaktadır. Bu konuda öğretimi gerçekleştirecek olan öğretmenlerimizin dil bilgisi konusunda donanımlı, bu bilgileri öğretebilecek ve dilimizi sevdirebilecek çeşitli yöntem ve teknikleri bilen, bilgilerini doğru aktarabilen bireyler olmaları gerekmektedir.

Keskinkılıç ve Keskinkılıç (2007: 245)'a göre ilk okuma yazma öğretiminin amacı, ilkokul çocuğunun psikolojisine ve seviyesine uygun; gerekli öğretme öğrenme yöntemleri, teknikleri ve materyalleri kullanarak okuma ve yazmanın temel becerilerini kazanmalarını sağlamaktır. Burada amaç kısa sürede okuma yazmaya geçmekten ziyade bu kazanımları hayatları boyunca severek ve zevk alarak yapmalarını sağlamaktır.

Erişen ve Çeliköz (2003)'e göre; Türkiye'nin çağdaş uygarlık düzeyinin üzerine çıkma hedefine, halen öğrenimine devam eden, gelecekte bu mesleği yapacak öğretmenlerin iyi yetiştirilmeleriyle ulaşılabileceği unutulmamalıdır.

Illk okuma yazma öğretimi ülkemizde önemini ve güncelliğini her zaman koruyan bir konu olmuştur. 2005 Türkçe öğretim programı ilk okuma yazmada kullanılan yöntem ve yazı türü konusunda değişiklikleri beraberinde getirmiştir. İlk okuma yazma öğretimi için ses temelli cümle yöntemi, yazı türü olarak da bitişik eğik yazının kullanılması benimsenmiştir. Yeni Türkçe öğretim programında düşünen, sorgulayan, bilgiye ulaşma yollarını bilen, çözüm odaklı bireyler yetiştirmek amaçlanmıştır. Bunun yanında bitişik eğik yazıyla etkili bir okuma yazma öğretimi gerçekleştirmek hedeflenmiştir (MEB, 2005).

Güneş (2017)'e göre; bitişik eğik yazı, harflerin birbirine bağlanarak 70 derece sağa eğik yazıldığı bir yazı türüdür. Bir harfin bittiği nokta ile bu harften sonra gelen harfin başladığı noktayı birbirine bağladığı için "bağlantılı yazı", "akıcı yazı" gibi isimler kullanılan bitişik eğik yazı 1380'li yıllardan bu yana kullanılmaktadır. Bayraktar (2006)'a göre; bitişik eğik yazıda hedef, harflerin görünümlerine dokunmadan hızlı ve akıcı yazmayı sağlamaktır. 
Güneş (2006); dik temel harflerle her harfin yazımından sonra durulduğu için yazı yazma sürecini yavaşlattığına ilişkin görüşte bulunmuştur. Bu durum düşünme sürecine etki etmektedir. Bununla beraber bitişik eğik yazıdaki devamlıık ile düşüncelerimizdeki devamlılık paralellik gösterdiğinden yazı yazarken elde edilen akıcılık okuma becerisine de yansımaktadır (MEB, 2005).

Dik temel harflerle okuma yazmada harfleri ters yüz etme, harflerde ayna görüntüsü oluşturma, hece ve kelimede harflerin yerini değiştirme ve yazım yönlerini karıştırma yanlışları olabilmektedir. Bitişik eğik yazıyla okuma yazmada ise bitişik eğik yazının yazım kurallarından kaynaklı, bu tarz yanlışların olma ihtimalinin daha düşük olduğu belirtilmiştir (Akyol, 2008).

2005 yılından 2017 yılına kadar ülkemizde yazma öğretiminde bitişik eğik yazı ile öğretim benimsenmiştir. 2017 yııına gelindiğinde ise Milli Eğitim Bakanlığı, gelecek eğitim öğretim yılında birinci sınıf okutacak sınıf öğretmenlerine dik temel yazı veya bitişik eğik yazıyla okuma yazma öğretimi konusunda tercih hakkı sunmuştur. Türkçe öğretim programında ise bu kararın uygulanacağı "ilk okuma yazma öğretimi dik temel harf yahut birleşik eğik harflerle gerçekleştirilir." şeklinde yer almıştır (MEB, 2017: 12). Bu durumda gerçekleşen yazı öğretimindeki karar ve tercih aşaması sonunda 20172018 öğretim yılı geçmiştir. Günümüze gelindiğinde ise ilk okuma yazma öğretiminde bitişik eğik yazı/dik temel yazı yerini yalnızca dik temel yazıya bırakmış durumdadır. Bu karar da Türkçe öğretim programında "ilk okuma yazma öğretimi tırnaksız dik temel harflerle gerçekleştirilir." şeklinde yer almaktadır (MEB, 2019: 10). Görüldüğü gibi sürekli değişime uğrayan bu mesele halen daha araştırmaya değer bir konu niteliği taşımaktadır.

Birçok tartışmaya yol açan bitişik eğik yazı uygulamasının gelecekte bu mesleği yapacak sınıf öğretmeni adayları tarafından nasıl bir görünüme sahip olduğu, ileride okuma yazma öğretecek kişiler olması açısından araştırımaya değer bir problem olarak görülmektedir. Bu araştırma 2005-2006 eğitim öğretim yılında uygulamaya konan yeni programın etkililiği konusunda geri dönüt sağlaması yönünden öneme sahiptir.

Yapılan araştırmaların genelinde öğretmen görüşleri ve öğrenci durumlarını incelemeye yönelik çalışmalar olduğu görülmektedir. Bunların yanında geleceğin sınıf öğretmenlerini araştırmaya dâhil eden çalışmaların sayısı ise azdır. Bununla birlikte 2005 yılında uygulanmaya başlanan Türkçe öğretim programının en dikkat çeken değişikliklerinden biri olan ilk okuma yazma öğretimi uygulamalarıyla okuma yazma öğrenen öğrencilerin ve öncesinde farklı yöntemlerle okuma yazma öğrenmiş bireylerin sınıf öğretmeni adayı olmuş olanlarının araştırmaya dâhil edilmesi bu araştırmanın farklılıklarından birisidir.

Bu çalışma ile ilk okuma yazmayı farklı yazı türleriyle öğrenen sınıf öğretmeni adaylarının bitişik eğik yazıya ilişkin görüşleri alınarak var olan durumun belirlenmesi, görüşlerinin değişkenlere göre farklılaşma durumlarının tespiti ve çözüm önerilerinin ortaya konulması amaçlanmaktadır. Buradan hareketle şu sorulara yanıt aranmıştır:

İlk okuma yazmayı dik temel yazı/bitişik eğik yazı ile öğrenen sınıf öğretmeni adaylarının;

1. Bitişik eğik yazı uygulamasına ilişkin görüşleri nelerdir?

2. Bitişik eğik yazı uygulamasına ilişkin görüşleri cinsiyete göre anlamlı bir fark göstermekte midir?

3. Bitişik eğik yazı uygulamasına ilişkin görüşleri öğrendikleri yazı türüne göre anlamlı bir fark göstermekte midir?

\section{Araştırmanın Modeli}

\section{Yöntem}

Araştırma, ilk okuma yazmayı farklı yazı türleriyle öğrenmiş sınıf öğretmeni adaylarının bitişik eğik yazı uygulamasına ilişkin görüşlerini belirlemek amacıyla betimsel tarama modeline göre gerçekleştirilmiştir. "Tarama modelleri, geçmişte olmuş veya şu anda var olmaya devam eden durumu olduğu haliyle betimlemeyi amaçlar. Araştırmaya konu olan durum, kişi veya nesne var olduğu gibi tanımlanır. Herhangi bir şekilde değiştirilmez ya da etkilenmez" (Karasar, 2008: 77).

\section{Örneklem}

Araştırmanın evrenini, 2018-2019 öğretim yılında Çanakkale Onsekiz Mart Üniversitesi Eğitim Fakültesi Temel Eğitim Bölümü Sınıf Eğitimi Anabilim Dalı́nda 3. ve 4. sınıfta öğrenimini sürdüren 
öğretmen adayları oluşturmaktadır. Bu evren üzerinden amaçlı örnekleme yoluyla seçilmiş sınıf öğretmeni adayları ise araştırmanın örneklemini oluşturmaktadır. Sonuç olarak araştırmada toplam 136 sınıf öğretmeni adayı ile çalışılmıştır. Araştırma kapsamında, görüşleri alınan sınıf öğretmeni adaylarının demografik özelliklerine ilişkin bilgiler Tablo 1'de sunulmuştur:

Tablo 1.

Araştırmaya Katılan Sınıf Öğretmeni Adaylarının Demografik Özellikleri

\begin{tabular}{|c|c|c|c|}
\hline & Grup & $f$ & $\%$ \\
\hline \multirow[t]{3}{*}{ Cinsiyet } & $\mathrm{KIz}$ & 110 & 80.9 \\
\hline & Erkek & 26 & 19.1 \\
\hline & Toplam & 136 & 100 \\
\hline $\begin{array}{r}\text { Illk okuma } \\
\text { a }\end{array}$ & Dik Temel Yazı & 81 & 59.6 \\
\hline yazmada öğrenilen yazı & ile Öğrenenler & & \\
\hline türü & $\begin{array}{r}\text { Bitişik Eğik } \\
\text { Yazıile Öğrenenler }\end{array}$ & 55 & 40.4 \\
\hline & Toplam & 136 & 100 \\
\hline
\end{tabular}

Araştırmaya katılan öğretmen adayları cinsiyet bazında değerlendirildiğinde $110 \mathrm{kız}, 26$ erkek öğretmen adayıyla çalışma yürütülmüştür. Araştırmaya katılan kızların oranı \%80.9 iken, erkeklerin oranı \%19.1'dir.

Araştırmaya katılan öğretmen adaylarının ilk okuma yazmada öğrenilen yazı türü değişkeni incelendiğinde araştırmaya katılan örneklemde 81 kişinin ilk okuma yazmayı dik temel yazı ile, 55 kişinin ise bitişik eğik yazıyla öğrendikleri belirlenmiştir. Öğrenilen yazı türü bazında oranlamaya bakıldığında ise katılımcıların \%59.6'sının dik temel yazı ile, \%40.4'ünün bitişik eğik yazı ile ilk okuma yazmayı öğrendikleri tespit edilmiştir.

\section{Veri Toplama Araçları}

Çalışmada, katılımcıların bitişik eğik yazıya yönelik görüşlerini ve görüşlerinin cinsiyete, öğrendikleri yazı türüne göre anlamlı fark gösterip göstermediğini belirlemek için Çakır (2012) tarafından geliştirilen ölçek sınıf öğretmeni adaylarına uyarlanarak kullanılmıştır. Araştırmanın amacıyla örtüşmesi için uzman görüşü alınarak 7 soru çıkartılmış, kalan 15 soruluk ölçek öğretmen adaylarına uygulanmıştır.

Maddelere verilen yanıtlarla hem madde boyutunda hem de ölçek boyutunda sınıf öğretmeni adaylarının bitişik eğik yazıya ilişkin görüşleri tespit edilmiştir. Tablo 2'de madde değer aralıklarına yer verilmiştir:

Tablo 2.

Bitişik Eğik Yazıya ilişskin Görüş Ölçeği Madde Değer Aralıkları

\begin{tabular}{llll}
\hline Değer Aralığı & $\begin{array}{c}\text { BEY'a İlişkin Görüş } \\
\text { Düzeyi }\end{array}$ & $\begin{array}{c}\text { Değer Aralığı (Toplam } \\
\text { puan) }\end{array}$ & $\begin{array}{c}\text { BEY'a İlişkin Görüş } \\
\text { Düzeyi }\end{array}$ \\
\hline $1.00-2.33$ & Olumsuz Görüş & $15-35$ & Olumsuz Görüş \\
$2.34-3.67$ & Kararsız Görüş & $36-55$ & Kararsız Görüş \\
$3.68-5.00$ & Olumlu Görüş & $56-75$ & Olumlu Görüş \\
\hline
\end{tabular}

Tablo incelendiğinde ölçeğe verilen yanıtların madde bazında ve ölçek geneli toplam puan anlamında ayrı ayrı değerlendirildiği görülmektedir. Buna göre her bir maddeden çıkan 1.00-2.33 olarak belirlenen en düşük değer aralığı için olumsuz görüş, 2.34-3.67 değer aralıklarında kararsız görüş, 3.685.00 değer aralıklarında ise olumlu görüş şeklinde ifade edildiği görülmektedir. Toplam puan olarak bakıldığında ise 15-35 arası olumsuz görüş, 36-55 arası kararsız görüş, 56-75 arası ise olumlu görüş olarak değerlendirilmiştir. 


\section{Verilerin Toplanması}

Ölçek uygulanmadan önce Çakır (2012)'dan kullanım için gerekli izin alınmıştır. Veri toplama aracı için izin alındıktan sonra uygulamanın yapılacağı kurumdan gerekli izinler alınmıştır. Ardından 2018-2019 öğretim yılı içerisinde Sınıf Eğitimi Anabilim Dalında öğrenim gören 3. ve 4. sınıf öğrencilerine uygun oldukları zaman dilimleri içerisinde araştırmacılar tarafından ölçek yüz yüze uygulanmış ve ölçeğin uygulanması yaklaşık olarak 20 dakika sürmüştür. Öğretmen adaylarının soruları içtenlikle cevaplamaları amacıyla gerekli açıklamalar hem ölçeğin başında yazılı olarak verilmiş hem de araştırmacı tarafından açıklanmıştır. Ölçek uygulanırken gönüllülük esas alınmıştır.

\section{Verilerin Analizi}

Araştırmanın amaçları kapsamında toplanan veriler SPSS 22 paket programı kullanılarak çözümlenmiştir. Ölçekte bulunan soruların analizinde, her bir maddenin frekans ve yüzdelik dağılımlarına bakılmıştır. Cinsiyete ve öğrenilen yazı türüne göre farklılaşma durumunu belirlemek adına da verilere bakıldıktan sonra parametrik testler uygulanmasına karar verilmiş ve bağımsız gruplar için t-Testi kullanılmıştır.

\section{Geçerlik ve Güvenirlik}

Çakır (2012) geliştirmiş olduğu ölçek için öncelikle ilgili alandan kaynak taraması yapmıştır. Ardından sorulacak soruların tespiti için bir ilköğretim okulunda çalışan 8 branş öğretmenine yaptırdığı “ilköğretim okullarındaki bitişik eğik yazı uygulamaları ile ilgili düşünceleriniz nelerdir?” konulu kompozisyon çalışmasıyla sorulacak soruların taslağını oluşturmuştur. Taslak form için iki uzman görüşüne başvurmuş gerekli düzeltmelerle ankete son halini vermiştir. Ölçekte yer alması kararlaştırılan 28 maddeden oluşan formun 60 ilköğretim branş öğretmeniyle ön uygulaması yapılmış ve çıkan sonuca göre faktör analizi yapılmıştır. Buna göre tek boyutlu hazırlanan ölçekte faktör yükü 0.5'in altında olan maddeler ölçekten çıkartılmıştır (Kerlinger, 1973: 461; Akt. Çakır, 2012). Buna göre faktör yük değeri 0,5'in altında olan 6 madde ölçekten çıkarılarak kalan 22 madde ile anket son halini almıştır. Kalan maddelerle ölçeğin Cronbach-Alpha değeri 0.945 şeklinde bulunmuştur.

\section{Etik Kurulu İzi}

2019 yılı mayıs ayında gerçekleştirilen bu araştırmada 2020 yılı öncesi araştırma verileri kullanılmış ve çalışma yüksek lisans çalışmasından üretilmiştir. Araştırma ve yayın etiğine uyulması için araştırmanın yapıldığı kurumlardan yasal izin alınmış ve araştırma bir proje desteğiyle yapılmıştır. Ayrıca araştırmada veri toplamak için kullanılan veri toplama aracı için de ölçeği kullanma izni alınmıştır.

\section{Bulgular}

Bu bölümde, araştırmanın amacına uygun olarak yapılan çalışmalar ile elde edilen bulgulara yer verilmiştir.

\section{İlk Okuma Yazmayı Farklı Yöntemlerle Öğrenen Öğretmen Adaylarının Bitişik Eğik Yazıya ílişkin Görüşlerinin Analizi}

"Bitişik Eğik Yazıya Illişkin Görüş Ölçeği"nde sınıf öğretmeni adaylarına sorulmuş olan 15 adet soruya verilen cevapların frekansları ve yüzdelik dağılımları Tablo 3'te verilmiştir: 
Tablo 3.

Bitişik Eğik Yazıya Iliş̧kin Görüş Ölçeği Maddelerinin; Frekans, Yüzde, Aritmetik Ortalama ve Standart Sapma Değerleri

\begin{tabular}{|c|c|c|c|c|c|c|c|c|c|c|c|c|}
\hline & \multicolumn{2}{|c|}{$\begin{array}{c}\text { Hiç } \\
\text { Katılmıyorum }\end{array}$} & \multicolumn{2}{|c|}{ Katılmıyorum } & \multicolumn{2}{|c|}{ Kararsızım } & \multicolumn{2}{|c|}{ Katılıyorum } & \multicolumn{2}{|c|}{$\begin{array}{l}\text { Tamamen } \\
\text { Katılıyorum }\end{array}$} & \multirow[t]{2}{*}{$\bar{x}$} & \multirow[t]{2}{*}{ Ss } \\
\hline & $f$ & $\%$ & $f$ & $\%$ & $f$ & $\%$ & $f$ & $\%$ & $f$ & $\%$ & & \\
\hline M1 & 65 & 47.8 & 51 & 37.5 & 12 & 8.8 & 4 & 2.9 & 4 & 2.9 & 1.7574 & .94670 \\
\hline M2 & 50 & 36.8 & 38 & 27.9 & 29 & 21.3 & 15 & 11.0 & 4 & 2.9 & 2.1544 & 1.12795 \\
\hline M3 & 50 & 36.8 & 47 & 34.6 & 35 & 25.7 & 4 & 2.9 & 0 & 0 & 1.9485 & .86341 \\
\hline M4 & 18 & 13.2 & 8 & 5.9 & 23 & 16.9 & 66 & 48.5 & 21 & 15.4 & 3.4706 & 1.21680 \\
\hline M5 & 57 & 41.9 & 45 & 33.1 & 27 & 19.9 & 5 & 3.7 & 2 & 1.5 & 1.8971 & .94500 \\
\hline M6 & 36 & 26.5 & 29 & 21.3 & 55 & 40.4 & 12 & 8.8 & 4 & 2.9 & 2.4044 & 1.06374 \\
\hline M7 & 55 & 40.4 & 50 & 36.8 & 16 & 11.8 & 10 & 7.4 & 5 & 3.7 & 1.9706 & 1.07456 \\
\hline M8 & 21 & 15.4 & 41 & 30.1 & 37 & 27.2 & 29 & 21.3 & 8 & 5.9 & 2.7206 & 1.13979 \\
\hline M9 & 43 & 31.6 & 44 & 32.4 & 34 & 25.0 & 12 & 8.8 & 3 & 2.2 & 2.1765 & 1.04621 \\
\hline M10 & 43 & 31.6 & 37 & 27.2 & 37 & 27.2 & 18 & 13.2 & 1 & 0.7 & 2.2426 & 1.06456 \\
\hline M11 & 100 & 73.5 & 22 & 16.2 & 6 & 4.4 & 5 & 3.7 & 3 & 2.2 & 1.4485 & .90937 \\
\hline M12 & 21 & 15.4 & 28 & 20.6 & 58 & 42.6 & 24 & 17.6 & 5 & 3.7 & 2.7353 & 1.04162 \\
\hline M13 & 79 & 58.1 & 34 & 25.0 & 10 & 7.4 & 12 & 8.8 & 1 & 0.7 & 1.6912 & 99267 \\
\hline M14 & 43 & 31.6 & 41 & 30.1 & 39 & 28.7 & 11 & 8.1 & 2 & 1.5 & 2.2206 & 1.24538 \\
\hline M15 & 35 & 25.7 & 29 & 21.3 & 46 & 33.8 & 21 & 15.4 & 5 & 3.7 & 2.5000 & 1.14180 \\
\hline Top. & & & & & & & & & & & 33.3382 & 9.94296 \\
\hline
\end{tabular}

M1 "Bitişik eğik yazı, dik temel yazıya göre daha okunaklıdır." ifadesine verilen yanıtlara bakıldığında 65 kişinin "hiç katılmıyorum" , 51 kişinin "katılmıyorum", 12 kişinin "kararsızım", 4 kişinin "katılıyorum", 4 kişinin ise "tamamen katılıyorum" olarak cevap verdiği görülmektedir. Oran olarak bakıldığında ise maddeyi cevaplayan öğretmen adaylarının, \%47.8'inin "hiç katılmıyorum", \%37.5'inin "katılmıyorum" olarak yanıtladığı görülmektedir. Bu oran toplamda araştırmaya katılanların \%85.3'ünü oluşturmaktadır. Maddeye "katılıyorum" ve "tamamen katılıyorum" cevabını verenlerin oranları \%2.9 ile toplam katııımcıların \%5.8'ini oluşturmaktadır. Maddeye verilen cevapların oranlarına bakıldığında araştırmaya katılan öğretmen adaylarının büyük çoğunluğunun bitişik eğik yazıyı dik temel yazıya göre okunaklı bulmadığı anlaşılmaktadır. Maddenin aritmetik ortalamasına bakıldığında 1.7574 olarak 
görülmektedir. Bu ölçeğin değer aralığına göre öğretmen adaylarının bu maddede bitişik eğik yazıya ilişkin olumsuz görüş (1.00-2.33 aralığı) sergiledikleri söylenebilir.

M2 "Bitişik eğik yazı, öğrencilerin yazı yazma hızlarını artırmaktadır." ifadesine verilen yanıtlara bakıldığında 50 kişinin "hiç katılmıyorum", 38 kişinin "katılmıyorum", 29 kişinin "kararsızım", 15 kişinin "katılıyorum", 4 kişinin ise "tamamen katılıyorum" olarak işaretlediği görülmektedir. Oran olarak bakıldığında ise \%2.9'unun "tamamen katılıyorum", \%11.0'ının "katılıyorum" cevabını verdiği görülmektedir. Soruya "katılıyorum ve tamamen katılıyorum" olarak cevap verenler toplamda araştırmaya katılanların \%13.9'unu oluşturmaktadır. Maddeye "hiç katılmıyorum" cevabını verenler \%36.8, "katılmıyorum" ifadesini tercih edenler ise \%27.9 ile toplam katılımcıların \%64.7'sini oluşturmaktadır. Oranlara bakılacak olursa öğretmen adaylarının çoğunluğunun görüşünün bitişik eğik yazının öğrencilerin yazı yazma hızlarını artırmadığı yönünde olduğu görülmektedir. Maddenin aritmetik ortalaması ise 2.1544; değer aralığına göre bitişik eğik yazıya ilişkin olumsuz görüş (1.00-2.33 aralığı) olarak tespit edilmiştir.

M3 "Bitişik eğik yazı, öğrencilerin okuma hızlarını artırmaktadır." ifadesine verilen cevaplar incelendiğinde 50 kişinin "hiç katılmıyorum", 47 kişinin "katılmıyorum", 35 kişinin "kararsızım", 4 kişinin "katılıyorum" olarak işaretlediği görülmektedir. Bu maddeye "tamamen katılıyorum" ifadesini ise hiçbir öğretmen adayı işaretlememiştir. Cevapların oranlarına bakacak olursak da \%36.8'inin "hiç katılmıyorum", \%34.6'sının "katılmıyorum" olarak toplamda katılımcıların \%71.4'ünü oluşturduğu görülmektedir. \%2.9'u ise "katılıyorum" olarak cevap vermiştir. Oranlara göre yorum yapacak olursak öğretmen adaylarının çoğunluğunun görüşünün bitişik eğik yazının öğrencilerin okuma hızlarını artırmadığı yönünde olduğu söylenebilir. Maddenin aritmetik ortalaması 1.9485; bitişik eğik yazıya ilişkin olumsuz görüş (1.00-2.33 aralığı) olarak bulunmuştur.

M4 "Bitişik eğik yazı daha estetiktir." Ifadesine verilen cevaplar incelendiğinde 18 kişinin "hiç katılmıyorum", 8 kişinin "katılmıyorum", 23 kişinin "kararsızım", 66 kişinin "katılıyorum", 21 kişinin ise "tamamen katılıyorum" olarak yanıtladığı görülmektedir. Oran olarak bakıldığında ise \%13.2 "hiç katılmıyorum", \%5.9 "katılmıyorum" olarak araştırmacıların \%19.1'ini oluşturduğu görülmektedir. \%48.5'i "katılıyorum", \%15.4'ü "tamamen katılıyorum" olarak işaretleyerek toplamda katılımcıların \% 63.9'unu oluşturmaktadır. Oranlara bakıldığında öğretmen adaylarının çoğunun bitişik eğik yazıyı estetik bulduğu yorumu yapılmaktadır. 3.4706 aritmetik ortalama ile ölçeğin değer aralığında bu maddeye katılımcıların bitişik eğik yazıya ilişkin kararsız görüş (2.34-3.67 aralığı) sergiledikleri söylenebilir.

M5 "Bitişik eğik yazıda öğrenci harfleri birbirine karıştırmaz." ifadesine verilen yanıtlar incelendiğinde 57 kişinin "hiç katılmıyorum", 45 kişinin "katılmıyorum", 27 kişinin "kararsızım", 5 kişinin "katılıyorum", 2 kişinin ise " tamamen katılıyorum" olarak işaretlediği görülmektedir. Oranlara bakacak olursak da \%41.9'u "hiç katılmıyorum", \%33.1'i "katılmıyorum" olarak toplam katılımcıların \% 75.0'ini oluşturmaktadır. \%3.7'si "katılıyorum" \%1.5'si ise "tamamen katılıyorum" olarak işaretlemiştir. Katılıyorum grubu toplamda araştırmaya katılanların \%5.2'sini oluşturmaktadır. Oranlara bakıldığında öğretmen adaylarının büyük çoğunluğu bitişik eğik yazıda harflerin karıştırılacağı yorumunda bulunduğu söylenebilir. Maddenin aritmetik ortalamasına bakıldığında, 1.8971 olduğu görülmektedir. Ölçeğin değer aralığında bu maddeye öğretmen adaylarının bitişik eğik yazıya ilişskin olumsuz görüş (1.00-2.33 aralığı) sergiledikleri yorumunda bulunulabilir.

M6 "Bitiş̧ik eğik yazı öğrencilerin anatomik yapısına uygundur." ifadesine verilen yanıtlar incelendiğinde 36 kişinin "hiç katılmıyorum", 29 kişinin "katılmıyorum", 55 kişinin "kararsızım", 12 kişinin "katılıyorum", 4 kişinin ise "tamamen katılıyorum" olarak işaretlediği görülmektedir. Oranlara bakacak olursak da \%26.5', "hiç katılmıyorum", \%21.3'ü "katılmıyorum" olarak toplamda araştırmaya katılanların \%47.8'ini oluşturmaktadır. \%8.8'i "katılıyorum", \%2.9'u ise "tamamen katılıyorum" işaretleyerek araştırmaya katılanların \%11.7'sini oluşturmaktadır. Oranlara bakarak yorum yapıldığında çoğunluğunun bitişik eğik yazıyı öğrencilerin anatomik yapısına uygun bulmadığı söylenebilir. Maddenin aritmetik ortalaması ise 2.4044 ile ölçeğin değer aralıklarında bitişik eğik yazıya ilişkin kararsız görüş (2.34-3.67 aralığı) ifadesine denk gelmektedir.

M7 "Yazı öğretiminin bitişik eğik yazı ile yapılmasını doğru buluyorum." ifadesine verilen yanıtlara bakıldığında 55 kişinin "hiç katılmıyorum", 50 kişinin "katılmıyorum", 16 kişinin "kararsızım", 
10 kişinin "katılıyorum", 5 kişinin ise "tamamen katılıyorum" olarak işaretlediği görülmektedir. Oran olarak bakıldığında ise araştırmaya katılanların \%40.4'ü "hiç katılmıyorum", \%36.8'i "katılmıyorum" olarak cevap vermiştir. Katılmıyorum grubu toplamda araştırmaya katılanların \%77.2'sini oluşturmaktadır. Maddeye "katılıyorum" diye cevap verenler \%7.4, "tamamen katılıyorum" ifadesini seçenler ise \%3.7 ile toplam katılımcıların \%11.1' ini oluşturmaktadır. Oranlara bakıldığında araştırmaya katılan öğretmen adaylarının çoğunluğunun yazı öğretiminin bitişik eğik yazı ile yapıımasını doğru bulmadığı söylenebilir. Maddenin aritmetik ortalamasına bakıldığında 1.9706 olarak bulunmuş ve bu değer ölçeğin değer aralıklarında bitiş̧ik eğik yazıya ilişkin olumsuz görüş (1.00-2.33 aralığı) ifadesine denk gelmektedir.

M8 "Bitişik eğik yazı alışkanlığı, dik temel harfle yazılan metinleri okumada problem çıkarmaz." ifadesine verilen yanıtlara bakıldığında 21 kişinin "hiç katılmıyorum", 41 kişinin "katılmıyorum", 37 kişinin "kararsızım", 29 kişinin "katılıyorum", 8 kişinin ise "tamamen katılıyorum" olarak işaretlediği görülmektedir. Oran olarak bakıldığında ise \%15.4'ü "hiç katılmıyorum", \%30.1'i ise "katılmıyorum" olarak cevap vermiştir. Bu oran toplamda araştırmaya katılanların \%45.5'ini oluşturmaktadır. Maddeye "katılıyorum" diye cevap verenler \%21.3, "tamamen katılıyorum" ifadesini seçenler ise \%5.9 ile toplam katılımcıların \% 27.2'sini oluşturmaktadır. Oranlara bakıldığında araştırmaya katılan öğretmen adaylarının çoğunluğu bitişik eğik yazı alışkanlığı, dik temel harfle yazılan metinleri okumada problem çıkarmaz maddesine katılmamıştır. Maddenin aritmetik ortalamasına bakıldığında 2.7206 olarak bulunmuş ve bu değer ölçeğin değer aralıklarında bitiş̧ik eğik yazıya ilişkin kararsız görüş (2.34-3.67 aralığı) ifadesine denk gelmektedir.

M9 "Bitişik eğik yazı kullanılması, öğrencileri yazmaya karşı isteklendirir." ifadesine verilen cevaplara bakıldığında 43 kişinin "hiç katılmıyorum", 44 kişinin "katılmıyorum", 34 kişinin "kararsızım", 12 kişinin "katılıyorum", 3 kişinin ise "tamamen katılıyorum" olarak işaretlediği görülmektedir. Oranlara bakacak olursak \%31.6'sı "hiç katılmıyorum", \%32.4'ü "katılmıyorum" olarak yanıtlamıştır. Bu oran toplamda araştırmaya katılanların \%64.0'ını oluşturmaktadır. Maddeye "katılıyorum" diye yanıt verenler \%8.8, "tamamen katılıyorum" ifadesini seçenler ise \%2.2 ile toplam katılımcıların \%11.0'ını oluşturmaktadır. Oranlardan anlaşılacağı gibi bu maddeye öğretmen adayları genel olarak katılmamıştır. Çoğu bitişik eğik yazının öğrencileri yazmaya karşı isteklendireceğini düşünmemektedir. Maddenin aritmetik ortalamasına bakıldığında 2.1765 olarak bulunmuş ve bu değer ölçeğin değer aralıklarında bitiş̧ik eğik yazıya ilişkin olumsuz görüş (1.00-2.33 aralığı) ifadesine denk gelmektedir.

M10 "Bitiş̧ik eğik yazı, öğrenciler arasındaki yazım farklııılarını azaltır." ifadesine verilen cevaplara bakıldığında 43 kişinin "hiç katılmıyorum", 37 kişinin "katılmıyorum", 37 kişinin "kararsızım", 18 kişinin "katılıyorum", 1 kişinin ise "tamamen katılıyorum" olarak işaretlediği görülmektedir. Oran olarak bakıldığında ise \%31.6'sı "hiç katılmıyorum", \%27.2'si "katılmıyorum" olarak yanıtlamıştır. Bu oran toplamda araştırmaya katılanların \% 58.8' ini oluşturmaktadır. Maddeye "katılıyorum" diye yanıt verenler \%13.2, "tamamen katılıyorum" diye yanıt verenler ise \%0.7 ile toplam katılımcıların \%13.9'unu oluşturmaktadır. Oranlara baktığımızda maddeye katılmayan grubun oranının daha yüksek olduğu görülmektedir. Araştırmaya katılan öğretmen adaylarının çoğu bitişik eğik yazının öğrenciler arasındaki yazım farklııklarını azaltacağını düşünmemektedir. Maddenin aritmetik ortalaması ise 2.2426 olarak bulunmuş ve bu değer ölçeğin değer aralıklarında bitişik eğik yazıya ilişkin olumsuz görüş (1.00-2.33 aralı̆ıı) ifadesine denk gelmektedir.

M11 "Günlük hayatta her zaman bitişik eğik yazı kullanırım." ifadesine verilen yanıtlara bakıldığında 100 kişinin "hiç katılmıyorum", 22 kişinin "katılmıyorum", 6 kişinin "kararsızım", 5 kişinin "katılıyorum", 3 kişinin ise "tamamen katılıyorum" seçeneğini işaretlediği görülmektedir. Oranlara bakıldığında ise \%73.5',i "hiç katılmıyorum", \%16.2'si "katılmıyorum" olarak yanıtlamıştır. Bu oran toplamda araştırmaya katılanların \%89.7'sini oluşturmaktadır. Maddeye "katılıyorum" diye yanıt verenler \%3.7, "tamamen katılıyorum" diye yanıt verenler ise \%2.2 ile toplam katılımcıların \%5.9'unu oluşturmaktadır. Oranları incelediğimizde araştırmaya katılan öğretmen adaylarının büyük çoğunluğunun bitişik eğik yazıyı günlük hayatında kullanmadığı anlaşılmaktadır. Maddenin aritmetik ortalaması da 1.4485 olarak bulunmuş ve bu değer ölçeğin değer aralıklarında bitişik eğik yazıya ilişkin olumsuz görüş (1.00-2.33 aralığı) ifadesine denk gelmektedir. 
M12 "Bitişik eğik yazıyla harflerin ters(geriye) çevirme durumu ortadan kalkmaktadır." ifadesine verilen yanıtlar incelendiğinde 21 kişinin "hiç katılmıyorum", 28 kişinin "katılmıyorum", 58 kişinin "kararsızım", 24 kişinin "katılıyorum", 5 kişinin ise "tamamen katılıyorum" seçeneğini işaretlediği görülmektedir. Oran olarak ise \%15.4'ü "hiç katılmıyorum”, \%20.6'sı "katılmıyorum" olarak yanıt vermiştir. Bu oran toplamda araştırmaya katılanların \%36.0'ını oluşturmaktadır. Maddeye "katılıyorum" diye yanıt verenler \%17.6, "tamamen katılıyorum" diye yanıt verenler ise \%3.7 ile toplam katılımcıların \%21.3'ünü oluşturmaktadır. Oranlara bakıldığında araştırmaya katılan öğretmen adaylarının daha büyük çoğunluğunun bitişik eğik yazıyla harflerin ters çevirme durumunu ortadan kaldırmadığı yönünde olduğu söylenebilir. Maddenin aritmetik ortalaması ise 2.7353 olarak bulunmuş ve bu değer ölçeğin değer aralıklarında bitişik eğik yazıya ilişkin kararsız görüş (2.34-3.67 aralığı) ifadesine denk gelmektedir.

M13 "Bitişik eğik yazı uygulamaları orta ve yükseköğretim dönemlerinde de devam ettirilmelidir." ifadesine verilen yanıtlara bakacak olursak 79 kişinin "hiç katılmıyorum", 34 kişinin "katılmıyorum", 10 kişinin "kararsızım", 12 kişinin "katılıyorum", 1 kişinin ise "tamamen katılıyorum" seçeneğini işaretledikleri görülmektedir. Oran olarak bakıldığında ise \%58.1'i "hiç katılmıyorum", \%25.0'ı "katılmıyorum" olarak cevaplamıştır. Bu oran toplamda araştırmaya katılanların \%83.1'ini oluşturmaktadır. Maddeye "katılıyorum" diye yanıt verenler \%8.8'ini oluştururken "tamamen katılıyorum" diyenler ise \%0.7'sini oluşturarak toplam katılımcıların \%9.5'idir. Oranlardan anlaşılacağı gibi araştırmaya katılan öğretmen adaylarının büyük çoğunluğunun bu maddeye katılmadığı görülmektedir. Birçoğu bitişik eğik yazının orta ve yükseköğretim dönemlerinde devam ettirilmesinin gerek olmayacağı düşüncesindedir. Maddenin aritmetik ortalaması da 1.6912 olarak bulunmuş ve bu da ölçeğin değer aralıklarında bitişik eğik yazıya ilişkin olumsuz görüş (1.00-2.33 aralığı) ifadesine denk gelmektedir.

M14 "Bitişik eğik yazı ile birlikte öğrenciler hızlı düşünme becerisi kazanmaktadır." ifadesine verilen yanıtlar incelendiğinde 43 kişinin "hiç katılmıyorum", 41 kişinin "katılmıyorum", 39 kişinin "kararsızım", 11 kişinin "katılıyorum", 2 kişinin ise "tamamen katılıyorum" seçeneğini işaretledikleri görülmektedir. Oran olarak bakıldığında \%31.6'sı "hiç katılmıyorum”, \%30.1'i "katılmıyorum" olarak yanıt vermiştir. Bu oran toplamda araştırmaya katılanların \%61.7'sini oluşturmaktadır. Maddeye "katılıyorum" diye yanıt verenler \%8.1, "tamamen katılıyorum" diye yanıt verenler ise \%1.5 ile toplam katılımcıların \%9.6'sını oluşturmaktadır. Oranlara göre bakıldığında araştırmaya katılan öğretmen adaylarının büyük çoğunluğunun; bitişik eğik yazının hızlı düşünme becerisine çok katkısı olmadığı yönünde düşündükleri söylenebilir. Maddenin aritmetik ortalaması ise 2.2206 olarak bulunmuştur, bu da ölçeğin değer aralıklarında bitişik eğik yazıya ilişkin olumsuz görüş (1.00-2.33 aralığı) ifadesine denk gelmektedir.

M15 "Bitişik eğik yazıyı kullanmak öğrencilerin dikkat becerilerini geliştirir." ifadesine verilen yanıtlar incelendiğinde 35 kişinin "hiç katılmıyorum", 29 kişinin "katılmıyorum", 46 kişinin "kararsızım", 21 kişinin "katılıyorum", 5 kişinin ise "tamamen katılıyorum" olarak işaretlediği görülmektedir. Oran olarak bakıldığında da \%25.7'sinin "hiç katılmıyorum", \%21.3'ünün "katılmıyorum" olarak yanıtladığı görülmektedir. Bu oran toplamda araştırmaya katılanların \%47.0’ını oluşturmaktadır. Maddeye "katılıyorum", diye yanıt verenler \%15.4, "tamamen katılıyorum" diye yanıt verenler ise \%3.7 ile toplam katılımcıların \%19.1'ini oluşturmaktadır. Oranlara bakıldığında, bitişik eğik yazıyı kullanmak öğrencilerin dikkat becerilerini geliştirir ifadesine araştırmaya katılan öğretmen adaylarının büyük bir kısmı katılmamıştır. Maddenin aritmetik ortalamasına bakıldığında 2.5000 olarak bulunmuş ve ölçeğin değer aralıklarında bitişik eğik yazıya yönelik kararsız görüş (2.34-3.67 aralığı) ifadesine denk gelmektedir.

Maddeler bütün olarak incelendiğinde ölçek genelinde toplam puanın aritmetik ortalaması 33.3382 olarak bulunmuştur. Bu da ölçeğin değer aralıklarında bitişik eğik yazıya ilişkin olumsuz görüş (15-35 aralığı) ifadesine denk gelmektedir. Buna göre yorum yapılacak olursa araştırmaya katılan öğretmen adaylarının birçoğunun bitişik eğik yazı uygulamasına ilişkin olumlu yönde görüş sergilemedikleri çıkarımında bulunulabilir. 


\section{Bitişik Eğik Yazı Uygulamasına İlişkin Görüşlerin Cinsiyete Göre Farklılaşma Durumu}

Bu başlıkta araştırmanın alt problemlerinden biri olan; ilk okuma yazmayı dik temel yazı/bitişik eğik yazı ile öğrenen sınıf öğretmeni adaylarının bitişik eğik yazı uygulamasına ilişkin görüşleri cinsiyete göre anlamlı bir fark göstermekte midir? sorusuna cevap aranmıştır.

Öğretmen adaylarının bitişik eğik yazıya ilişkin görüşlerinin cinsiyete göre toplam t-Testi sonuçları Tablo 4'te verilmiştir:

Tablo 4.

Öğretmen Adaylarının Bitişik Eğik Yazıya iliş̧kin Görüşlerinin Cinsiyete Göre t testi Sonuçları

\begin{tabular}{llllllll}
\hline Puanlar & Cinsiyet & $\mathrm{N}$ & $\overline{\mathrm{x}}$ & Ss & sd & $\mathrm{t}$ & $\mathrm{p}$ \\
\hline Toplam & Kız & 110 & 33.52 & 10.00 & 134 & 4.55 & .65 \\
& Erkek & 26 & 32.53 & 9.81 & & & \\
\hline
\end{tabular}

$\mathrm{p}<0.05$

Tablo 4'teki öğretmen adaylarının bitişik eğik yazıya ilişkin görüşlerinin cinsiyete göre t testi sonuçları incelendiğinde sorulara verilen cevapların toplam puanında istatistiksel olarak anlamlı bir farklılık görülmemektedir $\left[\mathrm{t}_{(134)}=4.55 ; \mathrm{p}>\right.$.05].

$\mathrm{K} \mathrm{Iz}$ öğrencilerin sorulara verdikleri cevapların ortalaması 33.52 iken, erkek öğrencilerin verdikleri cevapların ortalaması ise 32.53 olarak gerçekleşmiştir. Aradaki bu sayısal fark istatistiki olarak anlamsızdır. Bu sonuca göre kız ve erkek öğretmen adaylarının bitişik eğik yazıya ilişkin görüşlerinin birbirine yakın olduğu söylenebilir.

\section{Bitişik Eğik Yazı Uygulamasına ilişskin Görüşlerin Öğrenilen Yazı Türüne Göre Farklılaşma Durumu}

Bu başlık altında araştırmanın alt problemlerinden biri olan ilk okuma yazmayı dik temel yazı/bitişik eğik yazı ile öğrenen sınıf öğretmeni adaylarının bitişik eğik yazı uygulamasına ilişkin görüşleri öğrendikleri yazı türüne göre anlamlı bir fark göstermekte midir? sorusuna cevap aranmıştır.

Öğretmen adaylarının bitişik eğik yazıya ilişkin görüşlerinin öğrenmiş oldukları yazı türüne göre toplam t-Testi sonuçları Tablo 5'te verilmiştir:

Tablo 5.

Öğretmen Adaylarının Bitişik Eğik Yazıya ilişskin Görüşlerinin Öğrendikleri Yazı Türüne Göre t testi Sonuçları

\begin{tabular}{lllccccc}
\hline Puanlar & Yazı Türü & $\mathrm{N}$ & $\overline{\mathrm{x}}$ & $\mathrm{Ss}$ & $\mathrm{sd}$ & $\mathrm{t}$ & $\mathrm{p}$ \\
\hline Toplam & $\begin{array}{l}\text { Dik temel yazı ile } \\
\text { öğrenenler }\end{array}$ & 81 & 30.79 & 8.68 & 134 & -3.80 & $.00^{*}$ \\
& $\begin{array}{l}\text { Bitişik eğik yazı ile } \\
\text { öğrenenler }\end{array}$ & 55 & 37.09 & 10.55 & & & \\
\hline
\end{tabular}

${ }^{*} \mathrm{p}<0.05$

Tablo 5’te öğretmen adaylarının bitişik eğik yazıya ilişkin görüşlerinin öğrendikleri yazı türüne göre $t$ testi sonuçları incelendiğinde sorulara verilen cevapların toplam puanında anlamlı bir farklılık olduğu görülmektedir [ $\left.\mathrm{t}_{(134)}=-3.80 ; \mathrm{p}<.05\right]$.

Dik temel yazıyla öğrenenlerin ortalama puanı 30.79 iken, bitişik eğik yazıyla öğrenenlerin ortalama puanı ise 37.09 'dur. Aradaki bu sayısal fark bitişik eğik yazıyla öğrenenler lehine anlamlı görülmektedir. Buna göre ilk okuma yazmayı bitişik eğik yazıyla öğrenmiş öğretmen adaylarının bitişik eğik yazıya ilişkin görüşlerinin dik temel yazıyla öğrenenlere göre daha olumlu olduğu sonucu çıkarılabilir.

\section{Tartışma Sonuç ve Öneriler}

Yapılan araştırmada sınıf öğretmeni adaylarının bitişik eğik yazıya ilişkin görüşlerini, bu görüşlerinin cinsiyete ve ilk okuma yazmayı öğrendikleri yazı türüne göre anlamlı fark gösterip göstermediğini belirlemek amacıyla Çakır (2012) tarafından geliştirilen ölçekten yararlanılmıştır. 
Sınıf öğretmeni adaylarının ölçekteki sorulara verdikleri cevapların ortalama değerlerine bakıldığında, katılımcıların çoğunun bitişik eğik yazıya ilişkin olumsuz görüş sergiledikleri sonucuna varılmıştır. Buna benzer bir çalışma olan Sıcak, Arslan ve Ayan (2016) yapmış oldukları çalışmada sınıf öğretmenlerinin bitişik eğik yazıya yönelik tutumlarını olumsuza daha yakın düzeyde bulmuşlardır. Yine benzer bir çalışma olan Palavan ve Gemalmaz (2017)'ın “Eğik El Yazısıyla Okuma Yazma Öğrenen Öğrencilerin, Eğik El Yazısına Iliş̧kin Durumları" adlı araştırmaları sonucunda 65 öğrenciden bitişik eğik yazı için 22 olumlu 156 olumsuz ifade yer almıştır. Bu yönüyle araştırmanın sonucu bu çalışmaların bulgularıyla da paralellik göstermektedir.

Araştırmanın diğer alt problemi olan bitişik eğik yazıya ilişkin görüşlerin cinsiyete ve ilk okuma yazma öğrenilen yazı türüne göre anlamlı fark gösterip göstermediğine bakıldığında; sınıf öğretmeni adaylarının bitişik eğik yazıya yönelik görüşleri incelendiğinde toplamda cinsiyete göre anlamlı bir farklılık görülmemiştir. Bu bulguya göre kız ve erkek öğretmen adaylarının bitişik eğik yazıya yönelik görüşlerinin birbirine benzer olduğu söylenebilir.

Sınıf öğretmeni adaylarının bitişik eğik yazıya ilişkin görüşlerinde ilk okuma yazmayı öğrendikleri yazı türüne göre ise anlamlı bir farklılık görülmüştür. Buna göre ilk okuma yazmayı bitişik eğik yazıyla öğrenmiş öğretmen adaylarının bitişik eğik yazıya ilişkin görüşlerinin dik temel yazıyla öğrenenlere göre daha olumlu olduğu söylenebilir.

Pehlivan (2006) ilk okuma yazmaya geçiş sürecinde öğretmen ve öğrenci görüşlerine yer verdiği çalışmasında okul öncesi eğitim alan ve almayan ilkokul birinci sınıf öğrencilerinin ilk okuma yazmaya geçiş sürecini araştırmış ve öğrencilerin büyük kısmının bitişik eğik yazı yazarken zorlanmadıkları sonucuna ulaşmıştır. Yurduseven (2007) ilköğretim 1. ve 2. sınıf öğretmenlerinin görüşlerine dayanarak ilk okuma yazma programını değerlendirdiği araştırmasında öğretmenlerin, bitişik eğik yazı yazarken öğrencilerin zorlandıklarını belirttiklerini ifade etmiştir. Beyazıt (2007) yapmış olduğu çalışmada her iki ilk okuma yazma yöntemine ilişkin öğretmen görüşlerine yer vermiştir. Öğretmenler bitişik eğik yazının ilk etapta öğrencileri zorlayarak eğitimin kolaydan zora ilkesiyle çeliştiği, ancak estetik açıdan bitişik eğik yazının uygun olduğu ve yazıda akıcılığı sağladığı gibi görüşlerde bulunmuşlardır. Tok, Tok ve Mazı (2008) buna benzer yapmış oldukları çalışmada ilk okuma yazmada öğretilen her iki yöntemin de avantaj veya dezavantaja sahip olduğuna, ancak ses temelli cümle yönteminin olumlu taraflarının daha yüksek olduğu sonucuna ulaşmışlardır.

Özdemir (2008) gerçekleştirdiği çalışmasında bazı olumsuzluklar olsa da genel anlamda bitişik eğik yazı uygulamasının öğretmenler tarafından olumlu karşılandığı sonucuna ulaşmıştır. Gülbaş (2008) çalışmasında öğretmenlerin bitişik eğik yazıya ilişkin endişelerinin olduğunu, dik temel yazının yazımını daha kolay bulduklarını belirtmiştir. Durukan ve Alver (2008) yaptıkları çalışmada öğretmenlerin çoğunun öğrencilerin ses temelli cümle yöntemi ile okuma ve yazmayı daha hızlı öğrendikleri, öğretmenlerin hepsinin bitişik eğik yazı öğrenmenin dik temel harflerin okunmasını zorlaştırmadığı yönünde bitişik eğik yazıya ilişkin olumlu sonuçlara ulaşmışlardır. Özdemir (2019) sınıf öğretmenleriyle gerçekleştirdiği çalışmada sınıf öğretmenlerinin yazı tercihlerini araştırmıştır. Çalışmanın sonucuna göre sınıf öğretmenlerinin dik temel yazı ile metinlerin daha okunaklı olduğu ve tüm kitaplarda kullanılmasını tercih ettikleri yazı türü olduğunu belirten bulgulara yer vermiştir.

Yeni nesillere bakıldığında çocukların çoğunun yazı yazmaktan keyif almadıkları görülmektedir. Bu sebeple mesleğini devam ettiren sınıf öğretmenlerine, üniversitelerde öğrenim gören sınıf öğretmeni adaylarına ve okuma yazma alanında çalışan öğretim elemanlarına önemli görevler düşmektedir. Gelişen teknolojiyle beraber yeni kuşağa ayak uydurabilmek adına herkesin kendi alanında çalışmalar yapması ve kendini geliştirmesi gerekmektedir. Araştırmadan elde edilen sonuçlar doğrultusunda şu önerilerde bulunulmuştur:

İçinde bulunduğumuz yıllarda ilk okuma yazmaya sınıf öğretmenlerinin tercihleri doğrultusunda doğrudan bitişik eğik yazıyla başlanmayan durumlar daha çok olsa da yeniden bir değişikliğe gidilebileceği varsayımı dikkate alınarak fakültelerde eğitim gören öğretmen adaylarının her iki yazı türüyle de öğretim becerisini kazanmaları sağlanmalıdır.

Ilk okuma yazma ülkemizde sürekli değişkenlik gösteren bir konudur. Bu yönüyle araştırma konusu olarak her zaman güncelliğini korumaktadır. Bu nedenle konuyla ilgili farklı değişkenler göz önüne alınarak özellikle uygulamalı çalışmalar yapılabilir. 
Araştırmada yalnızca sınıf öğretmeni adaylarının fikirlerine değinilmiştir. Öğretmen adaylarına yol göstermesi açısından alanda çalışan öğretim elemanları ve sınıf öğretmenleri ile de çalışmalar yapılarak daha farklı sonuçlara ulaşılabilir.

\section{Kaynaklar}

Akyol, H. (2005). Türkçe ilk okuma yazma öğretimi. Ankara: Pegem A.

Akyol, H. (2008). Türkçe ilk okuma yazma ögrretimi. Ankara: Pegem A.

Babayiğit, Ö., Karabay, F.H., Metin, Z., \& Halıcı, B. (2018). Illkokul birinci sınıfta dik temel harflerle yazma öğretiminin incelenmesi. Uluslararası Türk Eğitim Bilimleri Dergisi, 6 (11), 45-61.

Beyazıt, N. (2007). ilk okuma yazma öğretiminin kazandırılmasında çözümleme yöntemi ve ses temelli cümle yönteminin farklı bakış açılarıyla değerlendirilmesi (Yayımlanmamış yüksek lisans tezi). Mustafa Kemal Üniversitesi, Sosyal Bilimler Enstitüsü, Hatay.

Çakır, Y. (2012). Ilköğretim ikinci kademedeki (6-7.sınıf) öğretmen ve öğrencilerin bitişik eğik yazıya ilişkin görüşleri. Mustafa Kemal Üniversitesi, Sosyal Bilimler Enstitüsü, Hatay, Yayınlanmamış Yüksek Lisans Tezi.

Durukan, E. ve Alver, M. (2008). Ses temelli cümle yönteminin öğretmen görüşlerine göre değerlendirilmesi. Uluslararası Sosyal Araştırmalar Dergisi, 1(5), 275-289.

Erişen, Y. ve Çeliköz, N. (2003). Öğretmen adaylarının genel öğretmenlik davranışları açısından kendilerine yönelik yeterlilik algıları. Türk Eğitim Bilimleri Dergisi, 1(4), 427-439.

Gülbaş, Ç. (2008). Yeni ilköğretim 1. sınıf ilköğretim programına ilişkin öğretmen ve öğrenci görüşleri. Muğla Üniversitesi, Muğla, Yayınlanmamış Yüksek Lisans Tezi.

Güneş, F. (2006). Niçin bitişik eğik yazı? MEB Bilim ve Aklın Aydınlığında Eğitim Dergisi, 71(1), 17-19.

Güneş, F. (2017). Bitişik eğik ve dik temel yazı savaşları. Sınırsız Eğitim ve Araştırma Dergisi, 2(3), 1-20.

Karadağ, R. (2016). Yazma eğitimi. Susar Kırmızı, F. (Ed.), illk ve ortaokullarda Türkçe öğretimi (ss. 163210). Ankara: Anı Yayıncılık.

Karasar, N. (2008). Bilimsel araştırma yöntemi (18. Baskı). Ankara: Nobel.

Keskinkılıç, K., \& Keskinkılıç, S.B. (2007). Türkçe ve ilk okuma yazma öğretimi. Ankara: Pegem A Yayıncılık.

Köksal, K. (1999). Okuma yazmanın öğretimi (1. Baskı). Ankara: Pegem A.

MEB (2005). İlköğretim Türkçe öğretim programı ve kılavuzu (1-5. Sınıflar). Ankara: Devlet Kitapları Müdürlüğü Basım Evi.

MEB (2017). Türkçe dersi öğretim programı (1- 8. Sınıflar). Erişim: file:///C:/Users/OEM/Downloads/33Tutkce-Ogretim-Programi-1.-Sinif-8.-Sinif.pdf

MEB (2019). Türkçe dersi öğretim programı (1-8. Sınıflar).Erişim: http://mufredat.meb.gov.tr/

Özdemir, N. (2008). ilköğretim yazı öğretiminde etkinliklerin değerlendirilmesi. Selçuk Üniversitesi, Konya, Yayınlanmamış Yüksek Lisans Tezi.

Özdemir, H. (2019). Temel eğitimde (1-2-3-4. Sınıflar) bitişik eğik yazı ve dik temel yazı uygulamaları konusunda öğretmen görüşleri (Meram ilçesi örneği). Necmettin Erbakan Üniversitesi, Eğitim Bilimleri Enstitüsü, Konya, Yayınlanmamış Yüksek Lisans Tezi.

Palavan, Ö. ve Gemalmaz, N. (2017). Eğik el yazısıyla okuma yazma öğrenen öğrencilerin, eğik el yazısına ilişkin durumları. Ana Dili Eğitimi Dergisi, 5(4), 589-607.

Pehlivan, D. (2006). Okul öncesi eğitim alan ve almayan öğrencilerin ilk okuma yazmaya geçiş sürecinin öğretmen ve öğrenci görüşleri doğrultusunda değerlendirilmesi. Çukurova Üniversitesi, Adana, Yayınlanmamış Yüksek Lisans Tezi.

Sıcak, A., Arslan, A. ve Ayan, C. (2016). Sınıf öğretmenlerinin bitişik eğik yazıya yönelik tutumlarının incelenmesi. Turkish Studies, 11(3), 2009-2024.

Tok, Ş., Tok, T. N. ve Mazı, A. (2008). Illkokuma yazma öğretiminde çözümleme ve ses temelli cümle yöntemlerinin değerlendirilmesi. Kuram ve Uygulamada Eğitim Yönetimi. 53. 123-144.

Yılmaz, Y. (2013). Yazma öğretimi. Yıldız, C. (Ed.), Türkçe öğretimi (ss. 217-295). Ankara: Pegem Akademi. 
Yurduseven, S. (2007). Illk okuma yazma öğretimi programının öğretmen görüşleri çerçevesinde değerlendirilmesi. Afyon Kocatepe Üniversitesi, Afyonkarahisar, Yayınlanmamış Yüksek Lisans Tezi.

\section{Introduction}

\section{Extended Abstract}

From 2005 to 2017, cursive handwriting style was adopted in writing education in our country. In 2017, the Ministry of National Education offered first grade teachers the right to choose to teach their students through manuscript or cursive handwriting styles. In the Turkish curriculum, it was stated that this decision would be implemented as "the first teaching to read and write is carried out with a manuscript letter or cursive letters." (MEB, 2017: 12) In this case, 2017-2018 academic year passed at the end of the decision and preference stage in the teaching of writing. As of today, in the first teaching of reading and writing, "manuscript or cursive handwriting" have been replaced by "manuscript writing". This decision is included in the Turkish curriculum as follows; "The first teaching to read and write is done with manuscript letters without quotes." (MEB, 2019: 10) As it is observed, this issue, which can be changed and is constantly changing, is still a subject worth investigating.

Cursive handwriting, leading to many discussions, is seen as a worthy problem to be researched in the future through the views of prospective classroom teachers who will do this profession in the future. Considering the fact that children who started primary school in and before 2005 are now at an undergraduate level (in our study; in the faculty of education), it may be seen as a historical opportunity to get the opinions of the people (prospective classroom teachers) who learned to read and write with different methods. This research is significant in terms of providing feedback on the effectiveness of the new program implemented in the 2005-2006 academic year. It is seen that there are studies examining teacher opinions and student situations in general on this subject. However, the number of studies investigating future classroom teachers is less. Also, one of the differences of this research is that it includes students who learned to read and write with the first literacy teaching practices which forms one of the most remarkable changes of the Turkish curriculum implemented starting from 2005, and those who have previously learned to read and write with different methods.

In this study, it is aimed to observe an existing situation, to investigate pre-service teachers' opinions according to the variables and to propose solutions by taking the opinions of the prospective classroom teachers who learn to read and write with different methods. Based on this, answers to the following questions were sought:

The prospective classroom teachers who learned to read and write through the manuscript handwriting/cursive handwriting;

- What are their opinions about the application of cursive handwriting?

- Do their opinions about the application of cursive handwriting show significant difference according to gender?

Do their opinions about the application of cursive handwriting show significant difference according to the handwriting method they were taught?

\section{Method}

The research was carried out by using descriptive scanning model in order to determine the opinions of the prospective teachers who learned the first literacy with different methods. Teacher candidates in the 3rd and 4th years of the primary school education department of a state university in the 2018-2019 academic year form the universe of this research. The classroom teacher candidates selected through purposive sampling through this universe constitute the sampling of the study. As a result, a total of 136 classroom teacher candidates were investigated in the research. In the study, a scale developed by Çakır (2012) was adapted to the prospective classroom teachers to determine the opinions of the participants about cursive handwriting and to observe whether their opinions differed significantly according to gender and the type of writing method they were taught with. In order to coincide with the aim of the research, upon having taken opinions from three field experts, 7 questions 
were prepared, and the other 15 questions scale was applied to prospective teachers. Before applying scales, necessary permission was obtained from Çakır (2012). Scales were applied face to face with permission from the deanery of the university. The data collected for the purposes of the research were analysed by using SPSS 22 package program. In the analysis of the questions, the frequency and percentage distributions of each item were examined. The t-Test was used for independent groups to determine the status of differentiation according to gender and type of writing method pre-service teachers were taught.

\section{Result and Discussion}

Considering the average values of the elementary teacher candidates' answers to the questions in the scale, it was concluded that most of the participants showed negative views about the cursive handwriting. In a study with similar findings, Sicak, Arslan and Ayan (2016) found the attitudes of classroom teachers towards cursive handwriting closer to negative. As a result of the research of Palavan and Gemalmaz (2017), which is also a similar study, 22 positive and 156 negative opinions were observed for cursive handwriting from 65 students. In this respect, the result of this study is in line with the findings of these studies. Considering whether the views of cursive handwriting differ significantly according to gender and the type of first literacy taught; about cursive handwriting, there was no significant difference in terms of gender in total. According to this finding, it can be concluded that the opinions of male and female teacher candidates towards cursive handwriting were similar. There was a significant difference in the opinions of the classroom teacher candidates about the cursive handwriting according to the type of writing method that they learned to read and write first. According to this, it can be said that the opinions of prospective teachers who learned to read and write with cursive handwriting towards cursive handwriting were more positive than those who learned with manuscript handwriting. 